\title{
Isolation and Properties of Napier Grass $\beta$-Amylase
}

\author{
Alex G. Alexander and Gene L. Spain ${ }^{1}$
}

\section{INTRODUCTION}

During the coming decades there are few greater challenges for plant scientists and growers alike than the achievement of maximum water utilization in the production of plant crops. It is widely recognized that vast areas of the United States receive too little moisture to support a viable agronomic or horticultural industry. Even where adequate water is always available the question of how water is used by plants-and consequently the most effective means of water management-remains essentially unanswered.

Unquestionably the development or discovery of plants which will produce well under conditions bordering on water deficiency would be highly desirable. A forage plant having such properties is Pennisetum purpureum Schum., commonly known as Napier grass. Although confined to tropic and sub-tropical areas with $\mathbf{4 0}$ inches or more annual rainfall, Napier grass remains relatively unaffected by water stresses that would severely damage or destroy other forages $(21,22)^{2,3}$. The authors felt that the study of mechanisms by which water is efficiently utilized in Napier grass should be highly instructive. The initial approach was directed at hydrolytic enzymes which employ water in critical, life-supporting reactions. The present paper deals with the isolation and properties of Napier grass amylase.

\section{EXPERIMENTAL PROCEDURE}

Amylase was prepared from the variety Merker taken from forage-trial plots at Solis Farm, Agricultural Experiment Station, Río Piedras, Puerto Rico. Following initial tests the enzyme was extracted exclusively from immature internodes. This is the counterpart of immature storage tissue in sugarcane. In mature Napier grass the tissue can be found at several locations on the plant owing to a tendency toward heavy branching. Although the stands of Napier grass sampled during the course of this work became progressively mature, the physiological age of immature internode tissue remained essentially constant.

For the standard preparation $10 \mathrm{~g}$. of tissue were excised from newly-cut stalks kept turgid in water. The tissues were ground at high speed with a

1 Plant Physiologist and Associate Agronomist, respectively, Agricultural Experiment Station, Mayagüez Campus, University of Puerto Rico, Río Piedras P.R.

2 Italic numbers in parentheses refer to Literature Cited, pp. 655.

A close relative, Pennisetum typhoides S. \& H., is planted extensively on lighttextured soils in the drier areas of tropical savannah regions (28). 
Waring Blender in chilled water and crushed ice. Separation of tissue debris was accomplished by expression through 8 layers of cheesecloth. Suspended matter was removed by centrifugation for 15 minutes at 2,500 r.p.m. Protein was precipitated from the supernatant liquid at $\mathrm{pH} 5.5$ with solid ammonium sulfate. The amylase-containing protein was dialyzed for several hours against two changes of distilled water and then refrigerated until needed for enzyme assay. New preparations were made at intervals of 2 to 3 days.

The standard amylase digest was composed as follows: $1.0 \mathrm{ml}$. of acetate buffer (0.2 M, pH 5.5), $1.0 \mathrm{ml}$. of soluble potato starch solution (1 percent), $0.25 \mathrm{ml}$. of enzyme preparation containing 6 to 10 units of amylase, and a control digest with $0.25 \mathrm{ml}$. of distilled water in place of enzyme preparation. The reaction was run for 1 hour at $37^{\circ} \mathrm{C}$. and was terminated by adding $1.0 \mathrm{ml}$. of dinitrosalicylic acid reagent (1) directly to the digest. Vessels were then heated in boiling water for color development and reducing sugar was determined by reference to a standard curve representing 0.025 to $0.100 \mathrm{mg}$. of maltose in $2.25 \mathrm{ml}$. of digest. Amylase activity was usually expressed as mg. of maltose produced per ml. per hour under conditions of the standard assay. Specific activity, activity units per mg. of protein, was also determined in which $0.10 \mathrm{mg}$. of maltose produced in $\mathbf{1 . 0}$ $\mathrm{ml}$. of digest per hour was taken as the standard activity unit.

Amylase preparations were further purified by gel filtration. The procedure has been described in detail for sugarcane leaf amylase (2). Sephadex G-2004 was soaked briefly in water and gradually packed by gravity in a $2.5 \times 36 \mathrm{~cm}$., air-free column. Ten to $12 \mathrm{ml}$. of amylase preparation were absorbed on the gel and eluted with distilled water. Four-ml. fractions of the effluent were collected and assayed for amylase by the colorimetric method described above.

Peak-activity fractions were concentrated by lyophilization and examined electrophoretically with a Beckman Model $\mathbf{R}$ paper electrophoresis system. Standard separations were run for 2 to 8 hours in $0.02 \mathrm{M}$ phosphate buffer, $\mathrm{pH}$ 8.0, with a constant current supply of 2.5 ma. Paper strips were air-dried, cut into 1-cm. sections, and eluted with distilled water. Amylase assays were conducted with the eluted protein. A 3-hour reaction period was used to accumulate adequate product levels since the amylase preparation was now very highly diluted.

Amylase products were examined by paper chromatography during several types of experiments. For this purpose samples were withdrawn periodically from active digests and inactivated by 10 minutes immersion in boiling water. These were clarified with the centrifuge and concentrated by lyophilization prior to spotting on Whatman no. 1 filter paper. Butanol-

- Farmacia of Fine Chemicals, Inc., Rochester, Minn., U.S.A. 
pyridine-water $(6: 4: 3, \mathrm{v} / \mathrm{v})$ was employed as solvent. Sugar spots were developed by the silver nitrate method of Dube and Nordin ( 8 ).

Throughout this paper frequent reference is made to sugarcane amylase. The latter has been studied intensively and serves as a convenient reference point in a second tropical grass having distinct water requirements.

\section{RESULTS AND DISCUSSION}

\section{DISTRIBUTION WITHIN THE PLANT}

Initial tests using clarified water extracts indicated a major amylase concentration in meristematic areas and within immature internodal tissues. Moderate activity was found in leaf blades, both young and mature, but little evidence of amylase was found in leaf sheaths. Traces of amylase were present in nodes. Practically no amylase activity could be found in mature internodes. This pattern corresponds closely to the amylase distribution in sugarcane $(5)^{5}$. While sugarcane has comparable amylase potential in leaf tissues, Napier grass appears to have a much greater concentration in meristematic and immature stalk areas. Again, the latter are not confined to a single growing point as in sugar cane; rather, they are found in numerous branches along a single main stem. We estimate that a mature Napier grass plant could easily contain 2 to 3 times more amylase than its sugarcane counterpart.

\section{SOLUBILITY}

The solubility of Napier grass amylase was ascertained by precipitation with ammonium sulfate, in 5-percent increments, between 5- and 60-percent saturation. Crude protein obtained in this manner was dialyzed for 2 hours and analyzed in accordance with the standard assay described above. No appreciable activity was recovered below 35 percent saturation (fig. 1). More than 90 percent of the amylase was obtained between 40 and 60 percent saturation.

Non-catalytic protein reached its maximum "salting out" velocity at about 40-percent saturation, somewhat less than amylase, so that the second half of the protein curve overlapped the first half of the amylase curve. Some degree of purification is thus afforded by taking only the 50-60 percent fraction from Napier grass extracts. If the entire 40 - to 60-percent area is desired it is still possible to gain 2.5- to 3 -fold purity increases by discarding all protein precipitated below 40 percent and that still in solution at 60 percent.

Sugarcane leaf amylase is slightly more soluble than the immat ire inter-

5 The immature internode tissue of Napier grass also contained large amounts of invertase. This again is very typical of sugarcane (6). 
node enzyme of Napier grass. About 90 percent of the activity is obtained between 48- and 66-percent saturation (2). From sugarcune one also derives traces of a second amylase which is believed to be an $\alpha$-type having a $\mathrm{pH}$ preference around $4.0(5)$. It is precipitated between 30 and 38 percent saturation. Napier grass yields no distinct enzyme in this area, although traces of amylase activity are recovered at levels as low as 5 percent (fig. 1).

\section{OPTIMUM PH AND TEMPERATURE; TIME-VELOCITY RELATIONSHIPS}

Employing dialyzed protein from the $38-60$ percent fraction, an amylase pH curve having a single peak at 5.5 was obtained (fig. 2). Sugarcane leaf

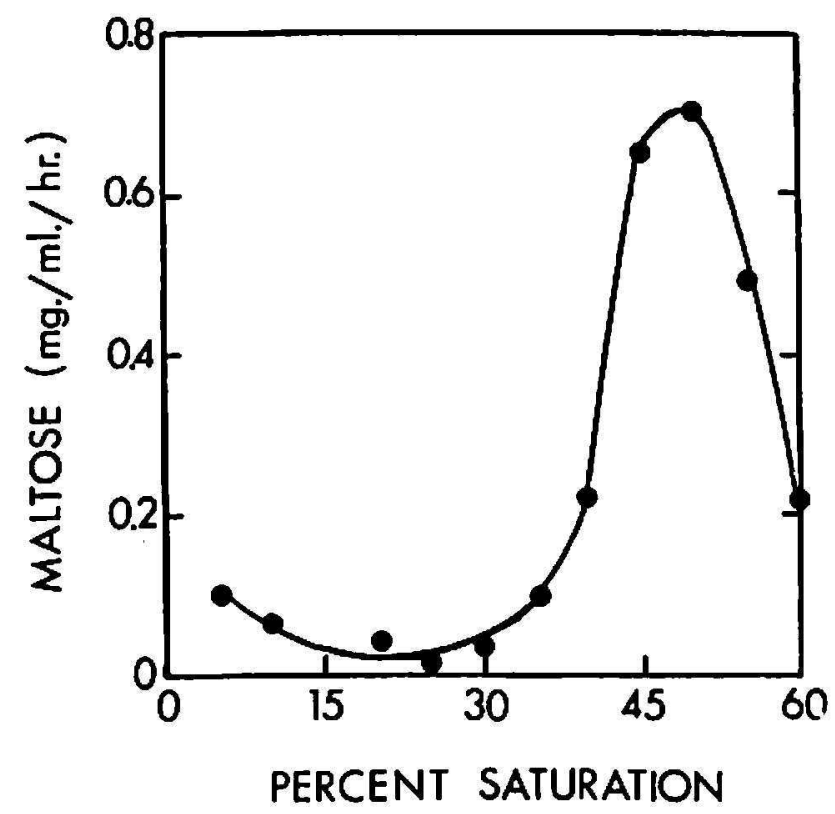

FIG. 1.-Solubility curve for Napier grass amylase. The enzyme was precipitated with ammonium sulfate from aqueous extracts of lyophilized immature stem tissue.

tissues yield a major amylase peak at $\mathrm{pH} 6.2$, and a lesser one at 3.5 to $4.0(2)$.

Experiments having temperature as a controlled variable revealed maximum activity at $46^{\circ} \mathrm{C}$., although temperature effects were essentially constant from $40^{\circ}$ to $52^{\circ} \mathrm{C}$. (fig. 3,A). The Napier grass enzyme thus appears to enjoy heat stability long after the velocity potential has been realized. Under in vivo conditions this property might help account for survival in the hot and alternately wet and dry tropical areas where the plant thrives. As is true of virtually all enzymes this catalyst is destroyed by immersion in boiling water (table 1). It is remarkable that immersion for 15 seconds had no effect, while traces of activity were still detected after 30 seconds.

Although the standard digest was usually run for 60 minutes a linear reaction could be plotted for at least 100 minutes (fig. 3,13). Howerer, by 
careful scrutiny the reader can observe that the data points in figure $3, \mathrm{~B}$, actually describe a flattened S-shaped curve. The linear curve, plotted on values determined by reducing-sugar assay, is misleading. It was later learned that a second enzyme, maltase, becomes active between 60 and 80 minutes. Thus the upward trend noted at 100 minutes represents a secondary product, glucose, as well as the primary product, maltose.

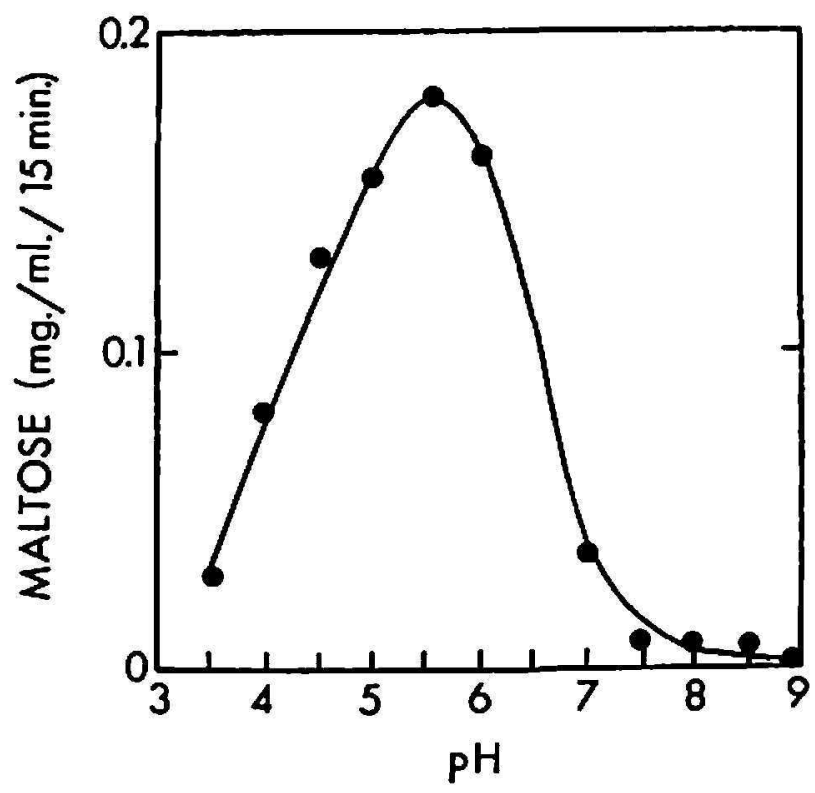

F1G. 2,-Behavior of Napier grass amylase at variable pH levels. The following buffers were employed: acetate, pH 3.0-5.5; succinate, pH 6.0-7.0; and tris (1rishydroxymethylamino methane), pH 7.5-9.0.

T.BLE 1.-Heal inactivation of Napier grass amylase ${ }^{1}$

\begin{tabular}{|c|c|c|c|c|c|c|}
\hline \multicolumn{7}{|c|}{ Enzyme pretreatment (seconds immersed in boiling water)- } \\
\hline 0 & 15 & 30 & 45 & 60 & 90 & 120 \\
\hline \multicolumn{7}{|c|}{ Mallose produced (mg. /ml./hr.)- } \\
\hline 2.04 & 2.00 & 0.21 & $\mathbf{0}$ & 0 & 0 & 0 \\
\hline
\end{tabular}

${ }^{1}$ Assay delails are described under experimental procedure.

\section{REACTION VELOCITY vs. SUBSTIRATE AND PROTEIN CONCENTRATION}

The amylase preparation used for optimum substrate and enzyme concentrations consisted of combined peak fractions obtained by filtration through Sephadex G-200. Response to increasing soluble starch was linear up to 0.2 percent (fig. $4, \mathrm{~A}$ ). Further substrate increases to 0.8 percent gave little additional activity. Soluble potato starch is not inhibitory at levels as high as 5 percent.

Activity response to increasing protein concentration remained linear to 

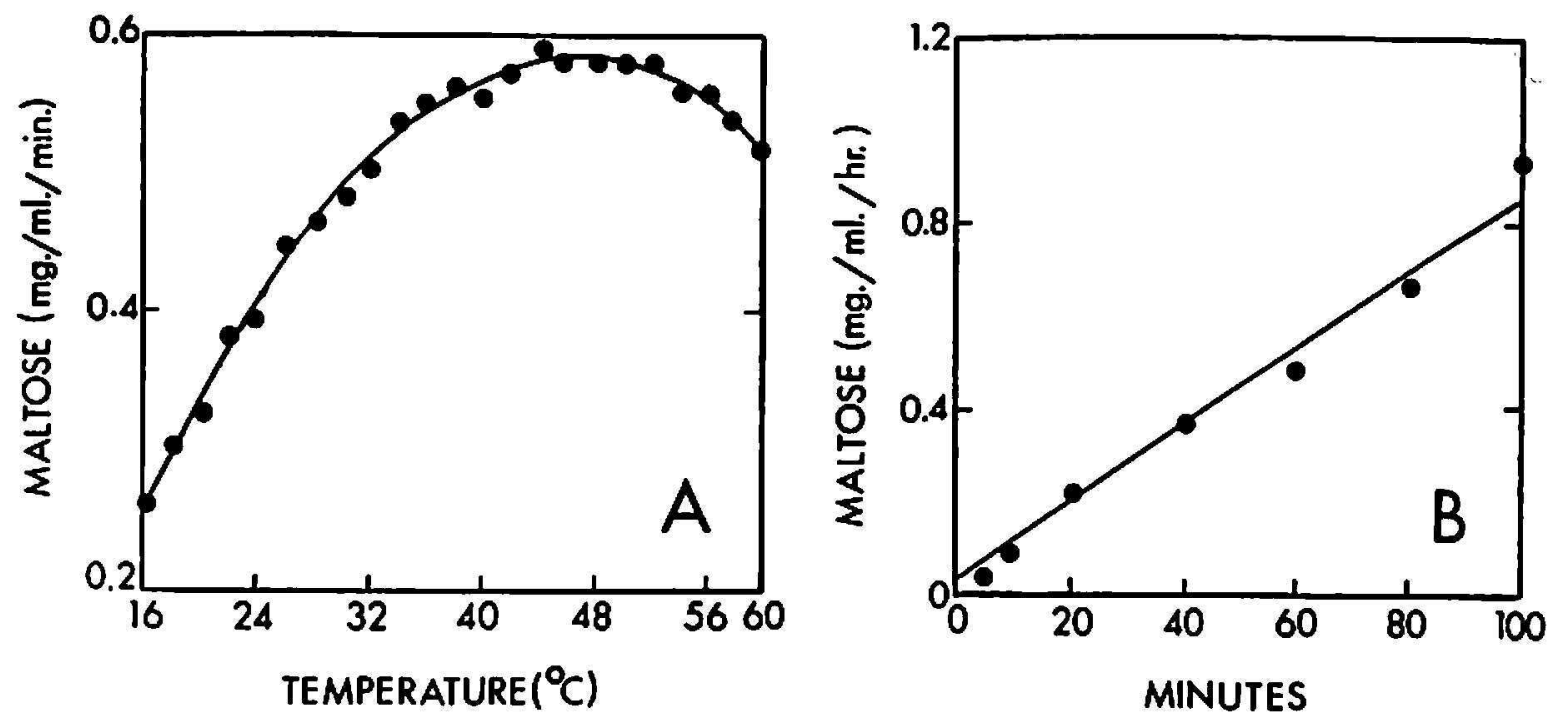

FIG. 3.-A, Response of Napier grass amylase (o variable temperature; B, limevelocity relationship linear for 100 mintes.
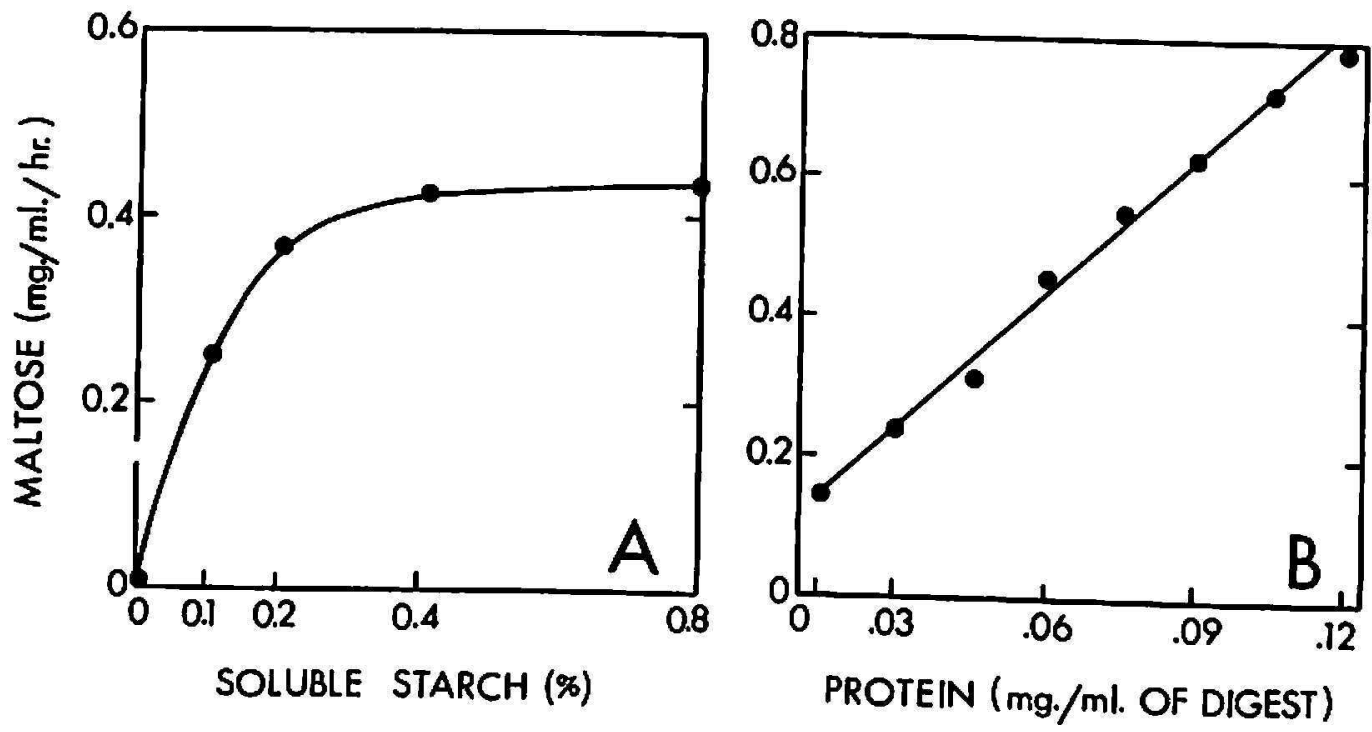

Fig. 4.- Reaction velocity of Napier grass amylase as a function of substrate concentration (A), and of enzyme concentration (B). Jetails of the standard assay are given under experimental procedure.

about $0.12 \mathrm{mg} . / \mathrm{ml}$. (fig. $4, \mathrm{~B}$ ). In practice only about 0.02 to $0.025 \mathrm{mg} . / \mathrm{ml}$. have been used in subsequent studies involving Napier grass amylase.

\section{j. GEL FILTRATION}

The principal benefit of filtration through Sephadex G-200 was to separate most of the amylase activity from the bulk of inert protein. As was true of sugarcane leaf amylase (2), the Napier grass enzyme moved more rapidly through the gel, allowing about 60 -percent recovery before the 
main protein front was received. In contrast to sugarcane amylase there was no evidence of a second activity peak (fig. 5). From the filtration data one can conclude that a single amylase of low molecular weight, or a group of small-sized amylases, has passed through the gel in a homogenous mass.

No evidence of endogenous activators or inhibitors was found during filtration experiments. On a specific-activity basis the gel filtration steps gave a 5 - to 7 -fold increase of purity.

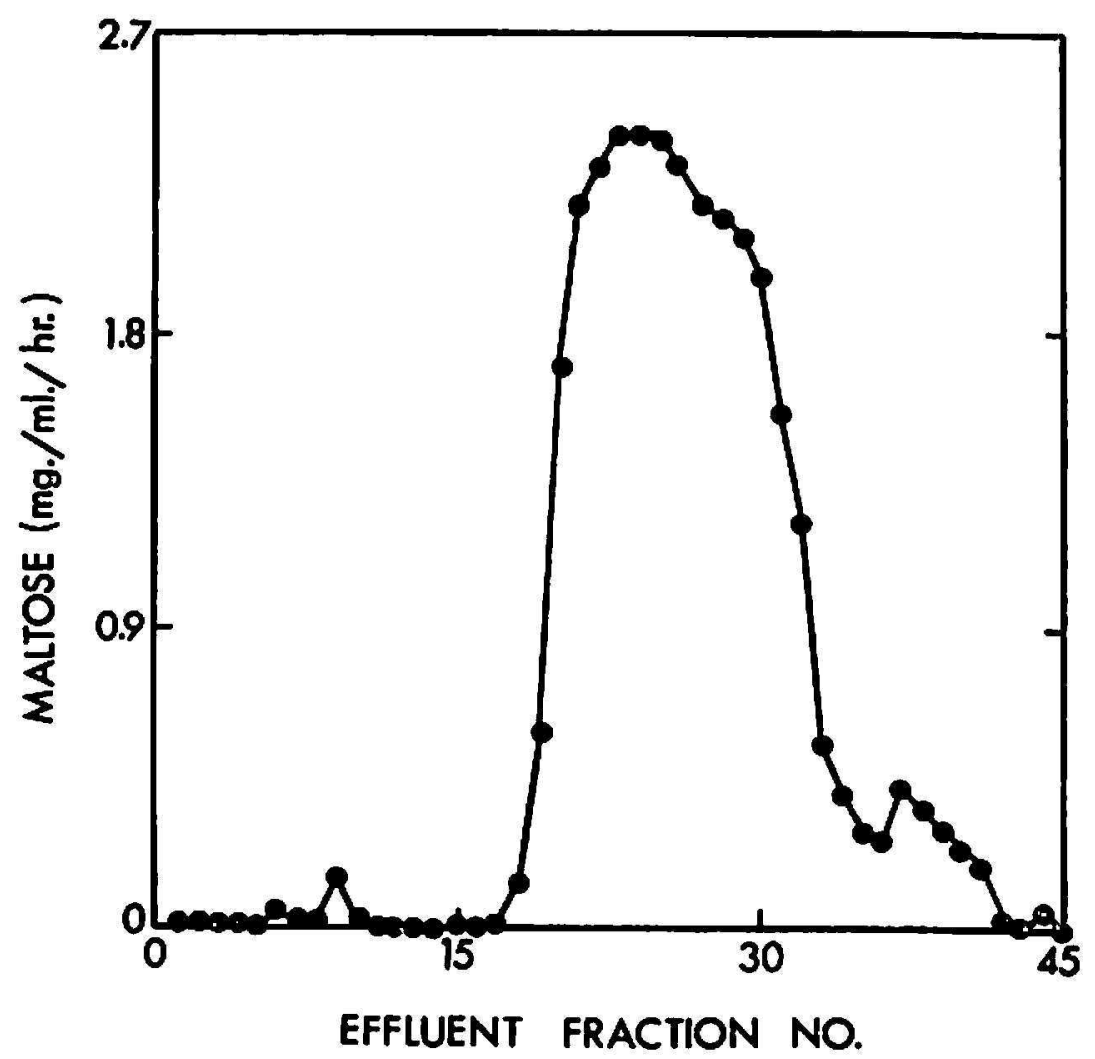

FIG. 5.-Gel filtration of Napier grass amylase. Fraction volume was $4 \mathrm{ml}$; flow rate was approximately $1 \mathrm{ml}$. per minute. Jetails of the amylase assay are given
under experimental procedure.

\section{ACTION PATTERN}

Paper chromatography of amylise digests was employed to gain a clearer picture of the enzyme's mode of action. Colorimetric reducing-sugar analyses do not in themselves tell us whether an alpha or beta type is at work. Figure 6 illustrates a paper chromatograph of digest samples collected from the time of reaction initiation (0 minutes) until the reaction's conclusion (120 minutes). Soluble potato starch was used as substrate. During this time the disaccharide maltose was the lone product (reference maltose is designated "Xa"). A similar result was obtained with amylo"e serving as substrate (fig. 7). Thus the beta type of amylase is clearly implicated. It is also evident that maltose was produced essentially as a function of 
MNUUTES

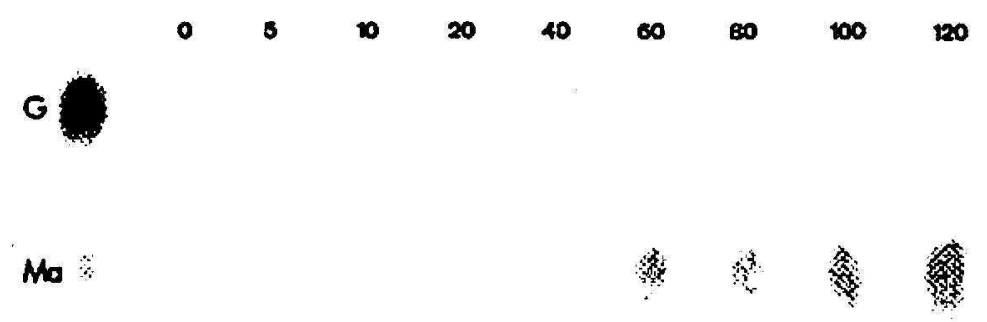

Fig. 6.-Paper chromatogram of digest samples for Napier grass amylase. The disaccharide maltose was the lone product, indicating that a $\beta$-amylase is active. Numbers indicate reaction time in minutes. The two reference sugars on the lefthand side are glucose $(G)$ and maltose (Ma), respectively. The substrate was soluble potato starch.

\section{NAPIER GRASS AMYLASE}

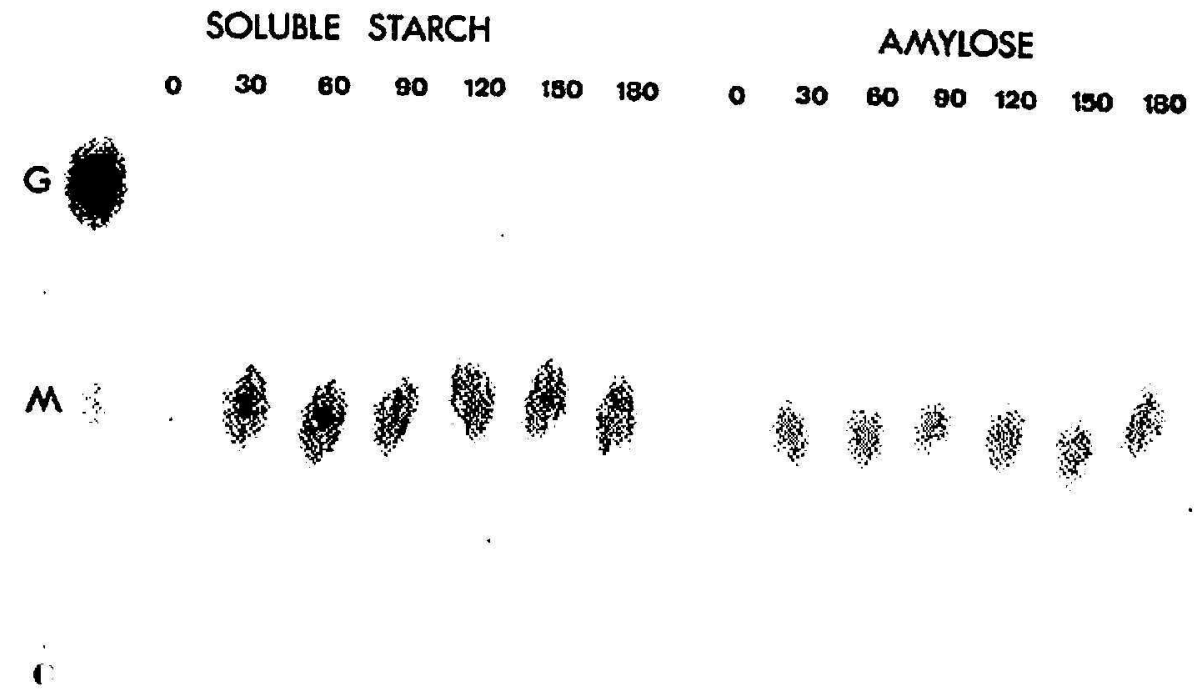

Fig. 7. Paper chromatogram of Napier grass amylase digests employing the substrates amyluse and soluble potato starch. 
time. Traces of the product were visible at 5 minutes and it continued to áccumulate for 2 hours (fig. 6).

During prolonged digestions a second product, glucose, became visible at about 4 hours (fig. $\$$ ). Since the possibility of microbial enzyme activity was minimized by toluene, it is concluded that a second enzyme, maltase, was latent in the amylase preparation. Presumably it was activated when its own substrate, maltose, accumulated to some critical level as a product of amylase. The importance of maltase lies in its ability to complete the degradation of starch by catalyzing the hydrolysis of maltose, thereby

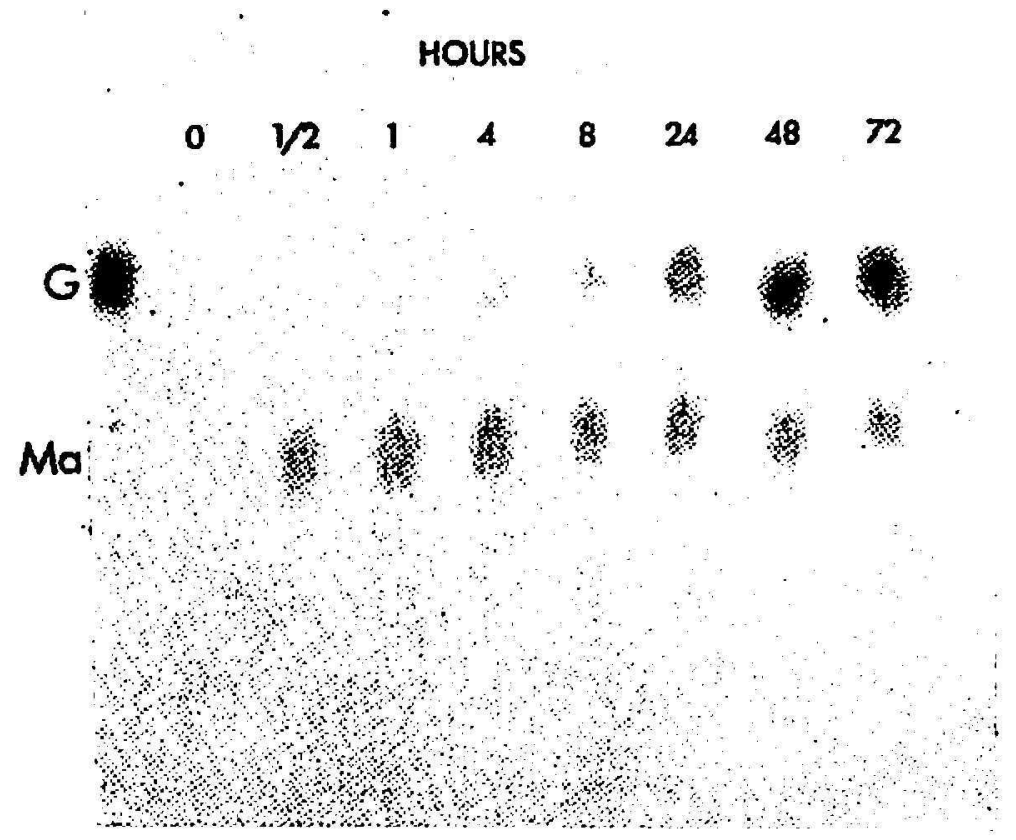

Fia. 8.-Paper chromatogram illustrating the appearance of a second product, glucose, during a prolonged reaction of Napier grass amylase against soluble potato starch. Glucose indicates the presence of maltase within the $\beta$-amylase preparation.

yielding two molecules of free glucose. The latter can then be rephosphorylated for entry into metabolic or synthetic pathways.

\section{SUBSTRATES}

Napier grass amylase was tested against a series of potential substrates. The standard digest was employed using 1-percent solutions of potato starch, corn starch, amylopectin, amylose, inulin and glycogen. Reactions were conducted under toluene and were extended for 54 hours. All substrates except inulin carried $\alpha-(1 \rightarrow 4)$-glucosidic linkages. Given adequate time the products maltose and glucose should have appeared fiom each substrate other than inulin. The latter is a polysaccharide comprised of 
some 33 fructofuranose units joined together by $\beta, 2 \rightarrow 1$-glycosidic bonds in a linear sequence (7). Inulin is attacked by inulase and fructosidase; improbable but nonetheless possible contaminants of the semi-purified amylase. However, chromatography of digest samples confirmed that no activity occurred against inulin, and that maltose plus glucose were in fact produced from each of the other substrates (fig. 9).

\begin{tabular}{|c|c|c|c|c|c|c|}
\hline & & & STR & O. & & \\
\hline & 1 & 2 & 3 & 4 & 5 & 6 \\
\hline G & 4 & d & 1 & 4 & & $y^{2}$ \\
\hline Mo '. & & : & & & & \\
\hline
\end{tabular}

Fic. 9.-Paper chromatogram of Napier grass amylase digests in which different substrates were incorporated. Substrates were: 1 , Soluble potato starch; 2 , corn starch; 3, amylopectin; 4, amylose; 5 , inulin, and 6 , glycogen. All substrates except inulin produced maltuse followed by glueose.

\section{8. $\mathrm{KM}$}

The Michaelis constant ( $\mathrm{Km}$ ) is probably the most fundamental of all enzyme constants. Assuming negligible product, it can be defined simply as the substrate concentration, in moles per liter, at half maximum velocity (8). In this instance $\mathrm{Km}$ is difficult to compute on a moles-per-liter basis. Employing instead the concentration value of this study, i.e., percent solution, Km can be estimated by use of the double reciprocal plot, velocity $v s$. substrate concentration, as illustrated by figure 10 . The actual value obtained for $\mathrm{Km}$ is 0.31 percent. The $\mathrm{Km}$ for sugarcane leaf amylase is 0.29 percent. Considering that only partial purification has been completed for eitheramylase, we could easily be dealing with a single enzyme insofar as $\mathrm{Km}$ is concerned. 


\section{ACTIVATORS AND INHIBITORS; STABILITY}

Napier grass amylase was readily inhibited by cyanide, lead, and iodide, much like its counterpart from sugarcane leaves (2). Recent studies (20) have shown that sugarcane amylase is thoroughly inhibited by sodium meta-silicate ( $\mathrm{Si}$ ). This element poses no health hazard and it is regarded

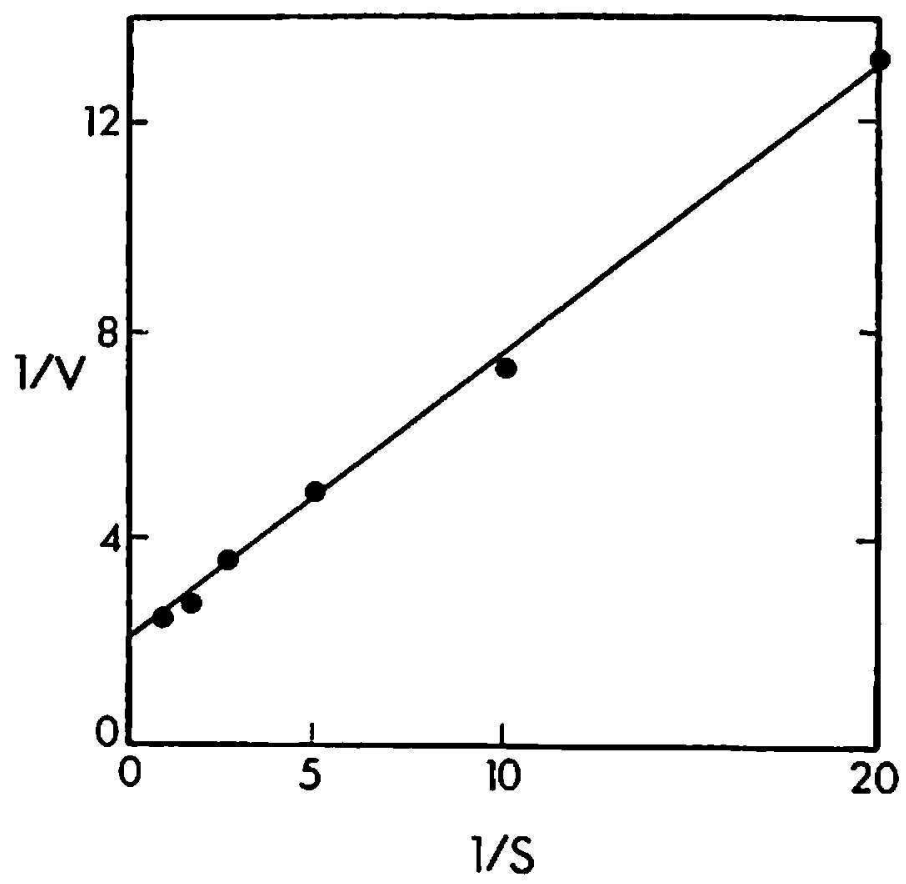

Fig. 10. - A Lineweaver-Burke plot for Napier grass amylase. Employing percen solution values for substrate concent ration, $\mathrm{Km}=0.31$.

TABLE: 2.-Silicon inhibition of Napier grass amylase ${ }^{1}$

\begin{tabular}{|c|c|c|c|c|c|c|c|c|c|}
\hline \multicolumn{10}{|c|}{ Si added ( $\mu$ moles $/ \mathrm{ml}$. of digest) - } \\
\hline " & 10 & 11 & 12 & 13 & 14 & 15 & 16 & 17 & 18 \\
\hline \multicolumn{10}{|c|}{ Mallese produced (mg./ml./hr.) - } \\
\hline 2.20 & 2.35 & 0.69 & 0.45 & 0.21 & 0.12 & 0.06 & 0 & 0 & 0 \\
\hline
\end{tabular}

${ }^{1}$ Assay details are described under experimental procedure.

as a potential regulatory agent for cane amylase. It was interesting to observe a similar abrupt inhibition of Napier grass amylase by Si (table 2). Inhibition was not prevented by increasing the substrate concentration, nor did appreciable recovery ccur following prolonged dialysis. Although approximately is times more Si was needed to inactivate Napier grass amylase, both enzymes were affected within a very narrow Si concentration range (2-3 $\mu$ moles $/ \mathrm{ml}$. 1s. 10-12 $\mu$ moles $/ \mathrm{ml}$.). This suggests that " physical restriction of the enzyme molecules had occurred, or that water involved in 
the hydrolysis became unavailable-perhaps being confined within a silica gel.

Prolonged dialysis of sugarcane leaf amylase led to inactivation. Activity was readily revived by adding traces of manganese or the sugars glucose, fructose, galactose or maltose. Dialysis gave no inactivation of Napier grass amylase other than that accountable to protein dilution. Manganese and sugar additives produced no stimulatory action. Whereas the active sugarcane enzyme is believed to be a protein-carbohydrate complex (4), Napier grass amylase appears to consist of protein free of readily-removable activators or cofactors.

It was observed that, when stored under toluene, amylase did not lose appreciable activity at laboratory temperatures, $22-23^{\circ} \mathrm{C}$., or when refrigerated at $4^{\circ} \mathrm{C}$. Deterioration began at about 90 hours when standing in a non-air conditioned room at temperatures ranging from 28 to $34^{\circ} \mathrm{C}$.

\section{ELECTROPHORESIS}

In spite of similarities it was obvious that Napier grass contained a different amylase than we had studied from sugarcane. Nonetheless the most tantalizing similarity of all was noted when protein samples were subjected to paper electrophoresis. Four distinct amylase peaks were obtained in a spatial distribution virtually identical to that of sugarcane leaf amylase (2). Quite curiously, three of the Napier grass peaks migrated toward the positive pole and one to the negative pole (fig. 11). Just the opposite was true of cane amylase. It is possible that the lack of a carbohydrate union with the Napier grass protein permits a greater number of negative charges to remain free. This in turn could drastically alter migration patterns while the total number of enzyme peaks remained unaffected.

\section{SIGNIFICANCE OF NAPIER GRABS AMYLABE}

Amylase is probably the "grandfather" of all enzymes; indeed, its history dates from the year 1814 when Kirchoff (9) discovered the amylase of wheat. Since that time the material published on amylases from grasses alone is voluminous. It is incontestible that amylase plays important roles during the germination of seed, and throughout the growth and development of the plant its essentiality is increasingly implicated. In sugarcane, perhaps more than any other enzyme, amylase determines the capacity to synthesize, accumulate and retain sucrose $(10,11,12,13,14,15,16,17,18)$.

Knowledge of $\beta$-amylase can be dated from 1897 when O'Sullivan (19) discovered that the primary end product is not just "sugar" but the specific disaccharide maltose. Within 2 years it was recognized that maltose is produced as a result of two distinct amylase types, alpha and beta, acting 
upon starch. The designation "alpha" or "beta" does not concern the configuration of the glycosidic bond being hydrolyzed, since both types of enzymes hydrolyze $\alpha(1 \rightarrow 4)$-glucosidic linkages. Beta amylases convert the amylose fraction of starch by attacking the nonreducing end of the polysaccharide chain, cleaving alternate $\alpha(1 \rightarrow 4)$-glucosidic bonds, and producing the disaccharide $\beta$-maltose. Within the heavily-branched or amylopectin portions of starch the action of $\beta$-amylase is stopped at the points of branching, i.e., at the $(1 \rightarrow 6)$-glycosidic linkages. Alpha-amylase attacks linkages in the interior of the polysaccharide chain with the subsequent production of oligosaccharides. No evidence of the alpha type was found in

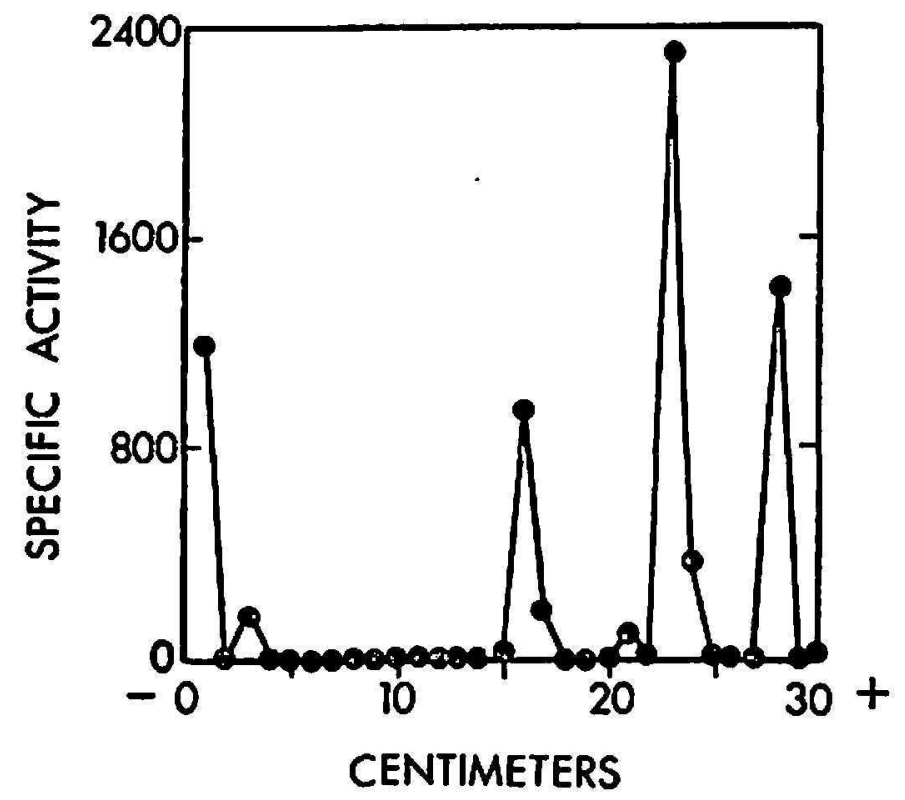

Fra. 11.-Flectrophoretic behavior of Napier grass amylase. Concentrated fractions obtained by gel filtration were applied in a narrow band at centimeter no. 15 and subjected to a 6-hour migration on paper strips saturated with phosphate buffer, pH 8.0. Power supply was constant at 2.5 ma. Paper strips were air dried, cut into 1 $\mathrm{cm}$. sections, and eluted with water. The standard amylase assay was then conducted as described under experimental procedure.

Napier grass preparations. This in itself suggests that in tissues experiencing high biochemical activity starch synthesis per se is not advanced beyond the level of amylose, which in turn is readily destroyed by $\beta$-amylase.

We have seen that Napier grass contains large amounts of a very rugged $\beta$-amylase-maltase complex. This enzyme or enzyme group should assure that glucose does not accumulate in "idle" polysaccharide forms in those tissues not specifically designed for storage. By the type reaction,

$$
\text { Glucose + ATP } \stackrel{\text { hexokinase }}{\longrightarrow} \text { Glucose-6-phosphate + ADP, }
$$


glucose will pass continually into metabolic pathways essential to normal growth and life processes. Highly-active amylase will also help maintain the starch-sucrose equilibrium in a favorable balance for grasses experiencing active growth, i.e., toward the left:

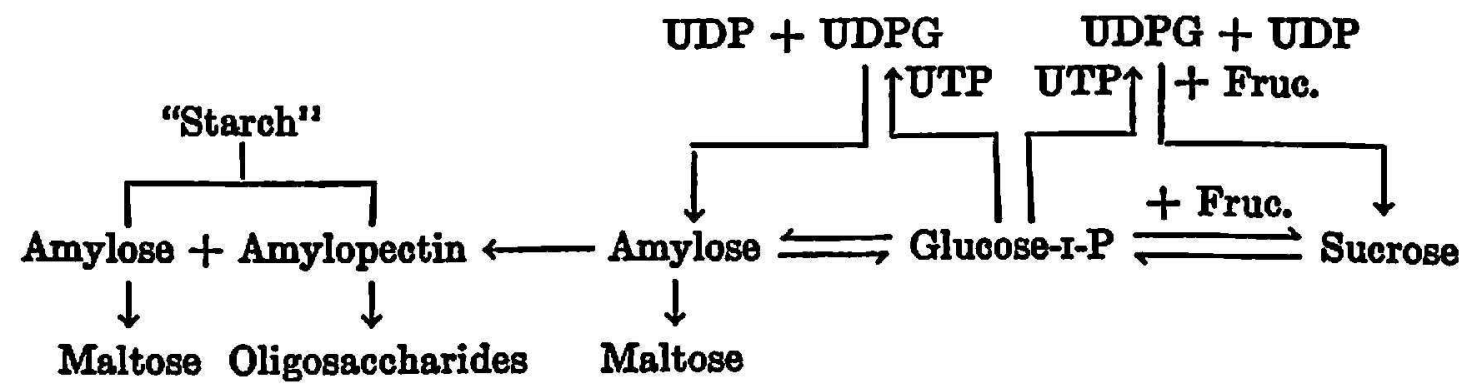

A factor of importance to Napier grass is the lessened likelihood of sucrose accumulations when $\beta$-amylase activity remains high. Should invertase levels be inadequate, the synthesis of sucrose would represent losses of essential hexose pools. The subsequent passage of sucrose into rarer sucrose configurations $^{6}$ must also be considered an indefinite loss of hexose to Napier grass biochemistry.

Most significant, however, is the knowledge that Napier grass amylase very closely resembles its counterpart in sugarcane. It is in fact more plentiful in Napier grass than in cane. Roles of the sugarcane enzyme have been scrutinized extensively for more than 5 years, and one might readily expect to find similar functions being performed by Napier grass amylase.

The unusually effective use of water by Napier grass very likely involves a major role by amylase. Amylase level and activity should receive continued attention. The next step includes direct comparisons of the cane and Napier grass amylases under conditions of severe water stress. Fundamental enzyme criteria should also be extended to include the hydrolytic ATP-ase and invertase systems of Napier grass.

\section{SUMMARY}

Studies of the forage plant, Napier grass, Pennisetum purpureum, have been started in an effort to clarify its exceptional water-utilizing capability. Hydrolytic enzymes are given primary attention. The present paper concerns a $\beta$-amylase from immature internode tissues. A much-studied amylase from sugarcane leaves served as a reference point for comparison of properties.

A standard assay for the amylase was established with soluble potato starch acting as substrate. The assay is suitable for large numbers of crude or semi-purified Napier grass extracts.

- Paper chromatograms of Napier grass leaf extracts have revealed significant quantities of raffinose, a sucrose-bearing trisaccharide. 
Amylase was heavily concentrated in meristematic and immature internodal tissues. Moderate amounts were present in leaf blades. Only traces were found in leaf sheaths and mature stem tissues. It was estimated that two to three times more amylase potential is present in Napier grass than in sugarcane.

Over 90 percent of the amylase was precipitated from clarified water extracts between 40- and 60-percent saturation with ammonium sulfate. Optimum pH was 5.5, and temperature $46^{\circ} \mathrm{C}$. The enzyme was heat stable up to $52^{\circ} \mathrm{C}$. Napier grass amylase remained stable for at least 2 weeks under refrigeration and for $\mathbf{9 0}$ hours at room temperature. Velocity relationships with time, protein concentration and substrate level were studied. $\mathbf{K}_{\mathbf{m}}$ for Napier grass amylase was virtually identical to that of sugarcane amylase.

Gel filtration experiments yielded amylase in a homogenous mass partially resolved from noncatalytic protein. Contrary to sugarcane, no evidence of a secondary, $\alpha$-amylase was present. Prolonged dialysis did not inhibit. Cyanide, lead, iodide, and meta-silicate did cause inhibition. Activation was not achieved with manganese or traces of sugar additives. No evidence was found indicating that the Napier grass amylase was a proteincarbohydrate complex, as is the case with sugarcane amylase.

Paper chromatography revealed that maltose was the lone primary product. After 4 hours the maltose was in turn hydrolyzed to free glucose by a maltase believed to be latent within the amylase preparation. The products maltose and glucose were obtained with potato starch, corn starch, amylose and amylopectin. The preparation was inactive against inulin.

Paper electrophoresis revealed four distinct amylase peaks. Three possessed a net negative charge and one a positive charge. Four peaks are also obtained with sugarcane amylase, but their net charges are opposite those of the Napier grass enzyme. This is taken as further evidence that, unlike sugarcane amylase, the Napier grass enzyme is not a protein-carbohydrate complex.

The biochemical significance of Napier grass amylase is discussed at length.

\section{RESUMEN}

Se han iniciado estudios sobre la yerba de pasto Pennisetum purpureum, yerba Napier, con el propósito de esclarecer su capacidad excepcional para utilizar el agua. Se presta primordial atención a las enzimas hidrolíticas. El presente trabajo tiene que ver con la $\beta$-amilasa de los tejidos inmaduros del entrenudo. La ya muy estudiada amilasa de las hojas de la cafía de azúcar sirvió como punto de referencia para la comparación de las propiedades.

Se estableció un análisis estándar para la amilasa con el almidón soluble 
de papa desempeñándose como el substrato. Este análisis es adecuado para un gran número de extractos crudos o semipurificados de la yerba Napier.

La amilasa estaba muy concentrada en el tejido meristemático y también en el tejido inmaduro entrenudal. Cantidades moderadas de ésta se encontraron en las láminas foliares, pero, en la yagua de la hoja y en el tejido maduro de la caña sólo se encontraron indicios. Se estimó que el potencial de amilasa en la yerba Napier es dos o tres veces más que en la cafía de azúcar.

Más del 90 por ciento de la amilasa se precipitó del extracto acuoso clarificado al saturarse con un $\mathbf{4 0}$ a un $\mathbf{5 0}$ por ciento de sulfato de amonio. El pH óptimo fué de 5.5 y la temperatura de $46^{\circ} \mathrm{C}$. La enzima permaneció estable al calor hasta los $52^{\circ} \mathrm{C}$., bajo refrigeración, por lo menos durante 2 semanas, y durante 90 horas a la temperatura de salón. Se estudiaron las relaciones de tiempo, concentración de proteina y nivel del substrato. El $K_{\mathrm{m}}$ para la amilasa de la yerba Napier fué virtualmente idéntico al de la amilasa de la cafía de azúcar.

Experimentos con filtración de gel culminaron en la separación de una masa totalmente homogénea de amilasa de la proteína no catalítica. Contrario a lo que ocurre en la cania de azúcar, no se encontró en este caso evidencia alguna de una $\alpha$-amilasa secundaria. La dílisis prolongada no inhibió la enzima. El cianuro, el plomo, el yoduro y el meta-silicato causaron inhibición. La activación no se logró con manganeso o con las cantidades insignificantes de azúcar que se affadieron. No se encontró evidencia alguna que indique que la amilasa de la yerba Napier es un complejo de proteína e hidratr de carbono, tal como sucede en la amilasa de la caña de azúcar.

La cromatografía sobre papel reveló que la maltosa es el único producto primario. Después de 4 horas la maltosa se hidrolizó a su vez liberando glucosa por una maltasa supuestamente latente durante la preparación de la amilasa. Se obtuvieron maltosa y glucosa del almidón de papa, del almidón de maír, de la amilosa y de la amilopectina. La preparación no actuó sobre la inulina.

La electroforesis en papel reveló cuatro puntos cimeros distintos de amilasa. Tres de los puntos poseían una carga negativa neta y uno una carga positiva. También se obtuvieron cuatro puntos cimeros en la amilasa de la caña de azúcar, pero sus cargas netas son contrarias a las de la enzima de la yerba Napier. Esto se considera como una prueba más de que la enzima de la yerba Napier, al contrario de la amilasa de la caña de azúcar no es un complejo de proteína e hidrato de carbono.

Se discute a plenitud el significado bioquímico de la amilasa de la yerba Napier.

\section{LITERATURE CITED}

1. Sumner, J. B., Dinitrosalicylic acid: A reagent for the estimation of sugar in normal and diabetic urine, J. Biol. Chem., 47: 5-9, 1821. 
2. Alexander, A. G., and Lebron, J., Isolation and purification of amylase from sugarcane leaves, Proc. 18th Cong. Intnl. Soc. Sugarcane Technol., 1968. Preprint no. A-91.

3. Dube, S. K., and Nordin, P., Isolation and properties of sorghum alpha-amylase, Arch. Biochem. and Biophys. 84: 121-7, 1961.

4. Alexander, A. G., Hydrolytic proteins of sugarcane: Amylase, J.Agr. Univ. P.R. 49 (3): 308-24, 1965.

5. - Hydrolytic proteins of sugarcane: The Q enzyme, J. Agr. Univ. P.R. 49 (2): 176-202, 1965.

6. - Hydrolytic proteins of sugarcane: The acid invertases, J. Agr. Univ. P.R. 49 (3) : 287-307, 1965.

7. Fruton, J. S., and Simmonds, S., General Biochemistry, 2nd ed., John Wiley \& Sons, Inc., New York, N. Y., p. 421, 1963.

8. Neilands, J. B., and Stumpf, P. K., Outlines of Enzyme Chemistry, John Wiley \& Sons, Inc., New York, N.Y., p. 98, 1964.

9. Sumner, J. B., and Somers, G. F., Chemistry and Methods of Enzymes, Academic Press, Inc., New York, N.Y., 1953.

10. Alexander, A. G., Sucrose-enzyme relationships in immature sugarcane as affected by variable nitrate and potassium supplied in sand culture, J.Agr. Univ. P.R. 48 (3): 165-231, 1964.

11. - Behavior of enzymes governing starch and sucrose-forming pathways in two sugarcane varieties supplied with variable nitrate and phosphate in sand culture, J. Agr. Univ. P.R. 49 (2): 153-75, 1965.

12. Alexander, A. G., Physiological studies of enzymes catalyzing the synthesis and hydrolysis of sucrose, starch, and phosphorylated hexose in sugarcane, J. Agr. Univ. P.R. 49(1): 60-75, 1965.

13. - The biosynthesis of starch in sugarcane, Proc. 18th Cong. Internatl. Soc. Sugar Cane Technol. 18: 625-38, 1865.

14. - High sucrose and abnormal enzyme activity as a function of nutritional stress in sugarcane, J.Agr. Univ.P.R. 51 (4): 325-33, 1967.

15. Alexander, A. G., and Samuels, G., Controlled-temperature studies of growth, enzymology, and sucrose production by two sugarcane varieties in Puerto Rico, J. Agr. Univ. P.R. 68(3): 204-17, 1968.

16. Alexander, A. G., The potential of sugarcane to produce sucrose, Proc. 18th Cong. Internatl. Soc. Sugar Cane Technol., 1968. Preprint no. S-29.

17. Alexander, A. G., and Montalvo-Zapata, R., Enzyme studies of sucrose decline in sugarcane desiccated with Paraquat, J. Agr. Univ. P.R., 63(4) : 230-50, 1969.

18. - Relationships of light to enzyme and sucrose transformations in sugarcane treated with Paraquat, J. Agr. Univ. P.R., 64(2): 264-296, 1970.

19. O'Sullivan, J., J. Chem. Soc. 29: 478, 1876. (Quoted from reference 9, p. 116).

20. Alexander, A. G., In vitro effects of silicon on hydrolytic and oxidative enzymes of sugarcane, Proc. 19th Cong. Internatl. Soc. Sugar Cans Technol., 1968. Preprint no. A-03.

21. Whyte, R. O., Moir, T. R. G., and Cooper, J. P., Las gramineas en la agricultura, FAO Estudios Agropecuarios No. 42,464 pp., Roma, 1959.

22. Pereira, R., Mauro, A., Sykes, D. J., Gomide, J. A., and Vidigal, G. T., Competicao de 10 gramineas para capineiras, no cerrado, Rev. Ceres 18(74): 141-53, 1966.

23. Begg, J. E., The growth and development of a crop of bulrush millet (Pennisetum typhoides S. \& H.), J. Agric. Sci. 65: 341-9, 1965. 